\title{
Twin Induced Reduction of Seismic Anisotropy in Lawsonite Blueschist
}

\author{
Seungsoon Choi ${ }^{1}$, Olivier Fabbri ${ }^{2}$, Gültekin Topuz ${ }^{3}$ D, Aral I. Okay ${ }^{3}$ and Haemyeong Jung ${ }^{1, *(D)}$ \\ 1 Tectonophysics Laboratory, School of Earth and Environmental Sciences, Seoul National University, \\ Seoul 08826, Korea; seungshum@snu.ac.kr \\ 2 UMR CNRS 6249, Université de Franche-Comté, 25030 Besançon, France; olivier.fabbri@univ-fcomte.fr \\ 3 Avrasya Yer Bilimleri Enstitüsü, İstanbul Teknik Üniversitesi, 34469 İstanbul, Turkey; \\ topuzg@itu.edu.tr (G.T.); okay@itu.edu.tr (A.I.O.) \\ * Correspondence: hjung@snu.ac.kr; Tel.: +82-2-880-6733
}

Citation: Choi, S.; Fabbri, O.; Topuz, G.; Okay, A.I.; Jung, H. Twin Induced Reduction of Seismic Anisotropy in Lawsonite Blueschist. Minerals 2021, 11, 399. https://doi.org/10.3390/ $\min 11040399$

Academic Editor: Paris Xypolias

Received: 10 February 2021

Accepted: 7 April 2021

Published: 10 April 2021

Publisher's Note: MDPI stays neutral with regard to jurisdictional claims in published maps and institutional affiliations.

Copyright: () 2021 by the authors. Licensee MDPI, Basel, Switzerland. This article is an open access article distributed under the terms and conditions of the Creative Commons Attribution (CC BY) license (https:// creativecommons.org/licenses/by/ $4.0 /)$.

\begin{abstract}
Lawsonite is an important mineral for understanding seismic anisotropy in subducting oceanic crust due to its large elastic anisotropy and prevalence in cold subduction zones. However, there is insufficient knowledge of how lawsonite twinning affects seismic anisotropy, despite previous studies demonstrating the presence of twins in lawsonite. This study investigated the effect of lawsonite twinning on the crystal preferred orientation (CPO), CPO strength, and seismic anisotropy using lawsonite blueschists from Alpine Corsica (France) and the Sivrihisar Massif (Turkey). The CPOs of the minerals are measured with an electron backscatter diffraction instrument attached to a scanning electron microscope. The electron backscatter diffraction analyses of lawsonite reveal that the $\{110\}$ twin in lawsonite is developed, the [001] axes are strongly aligned subnormal to the foliation, and both the [100] and [010] axes are aligned subparallel to the foliation. It is concluded that the existence of twins in lawsonite could induce substantial seismic anisotropy reduction, particularly for the maximum S-wave anisotropy in lawsonite and whole rocks by up to $3.67 \%$ and $1.46 \%$, respectively. Lawsonite twinning needs to be considered when determining seismic anisotropy in the subducting oceanic crust in cold subduction zones.
\end{abstract}

Keywords: lawsonite; twin; blueschist; crystal preferred orientation; seismic anisotropy

\section{Introduction}

Seismic anisotropy, which is useful for studying tectonic fabric in the Earth, has been widely observed in subduction zones [1-4], including subducting oceanic slabs [5,6]. It can be caused by the crystal preferred orientation (CPO) of elastically anisotropic minerals [7,8]. Since lawsonite is an elastically anisotropic mineral in blueschist and eclogite facies rocks at the top of the subducting slab in cold subduction zones, the development of the CPO of lawsonite could cause substantial seismic anisotropy. The CPO of lawsonite has been used to interpret various seismic anisotropies observed in cold subduction zones from naturally and experimentally deformed lawsonite-bearing rocks such as blueschist and eclogite [9-14].

Several studies performed in the last decade have shown the existence of twins in lawsonite from the Sivrihisar Massif (Turkey) [10,15,16], South Motagua (Guatemala) [16,17], Southern New England Orogen (Australia) [18], Alpine Corsica (France) [19], and experimentally deformed lawsonites [14]. However, there is an insufficient understanding of how lawsonite twinning affects seismic anisotropy. In this study, the effect of lawsonite twinning on the CPO, CPO strength, and seismic anisotropy of lawsonite was investigated utilizing natural lawsonite blueschists collected from Alpine Corsica (France) and the Sivrihisar Massif in the Tavşanlı Zone (Turkey). The main focus of this study is the direct effect of twins in lawsonite on the seismic anisotropy. We compare the CPO and seismic anisotropy of lawsonite in four natural samples with those of the modelled samples where 
the twins are not considered. The results show that the existence of lawsonite twins could induce reductions in the $\mathrm{CPO}$ strength of lawsonite and whole rock, as well as the resultant seismic anisotropy, which is caused by the CPO of elastically anisotropic minerals in cold subduction zones.

\section{Geological Overview}

Alpine Corsica (France) is part of the Alpine orogenic belt [20,21] and mainly consists of Schistes Lustrés that were deposited on the seafloor of a branch of the Tethys Ocean and underwent high-pressure, low-temperature (HP-LT) metamorphism in a subduction zone [22-25]. The estimated metamorphic pressure-temperature conditions for the blueschist and eclogite facies conditions are $\mathrm{P}=1.0$ and $2.4 \mathrm{GPa}$, and $\mathrm{T}=420$ and $520^{\circ} \mathrm{C}$, respectively $[16,22-24,26]$. The blueschist and eclogite metamorphisms are dated at $\sim 37$ and $\sim 34$ Ma utilizing the Lu-Hf in lawsonite and garnet, respectively $[16,22,27]$. A portion of the Schistes Lustrés in Alpine Corsica, Monte Pinatelle (study area) also experienced HP-LT metamorphism and primarily consists of lawsonite blueschist and eclogite [22,23,28].

The Tavşanlı Zone in Turkey is an Alpine high-pressure belt and was formed during the Mesozoic convergence between Eurasia and the Anatolide-Tauride Block [29-31]. The timing of HP-LT metamorphism is estimated by $\mathrm{Rb}-\mathrm{Sr}$ phengite and $\mathrm{Lu}-\mathrm{Hf}$ garnet as ca. $80 \mathrm{Ma}$ and 86-92 Ma, respectively [32,33]. As a part of the Tavşanlı Zone, the Sivrihisar Massif mainly consists of high-pressure metamorphic rocks [34], and the Halilbağ1 region (study area) in the Sivrihisar Massif includes several types of lawsonite blueschist and eclogite. The estimated peak pressure and temperature conditions are 1.2-2.5 GPa and $350-650{ }^{\circ} \mathrm{C}[10,35]$.

In this study, lawsonite blueschist samples were collected from Alpine Corsica in Monte Pinatelle, France, and the Halilbağ 1 area in the Tavşanlı Zone, Turkey (Figure 1a,b). Both regions are considered to be structurally coherent terrains [16] and experience progressive lawsonite blueschist metamorphism and rapid exhumation [22,35,36]. The Monte Pinatelle outcrop shows a well-foliated blueschist body (Figure 1c) in contact with weakly foliated metagabbro. The Halilbağ 1 lawsonite blueschists and eclogites exhibit a steeply dipping foliation and a mineral compositional layering (Figure 1d). 

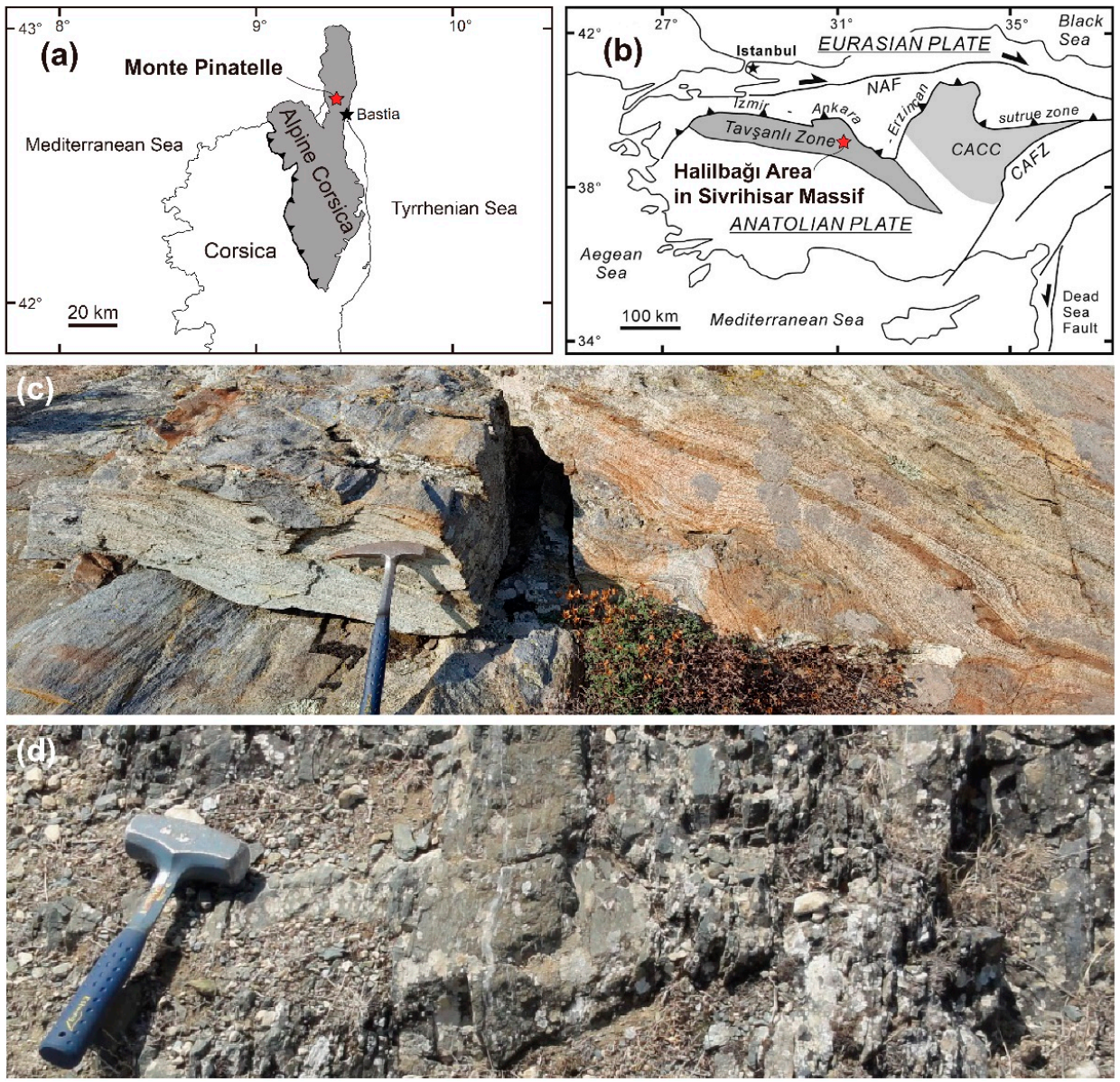

Figure 1. (a) Simplified tectonic map of Alpine Corsica (France) with sample locations indicated by red star (samples 3034 and 3033), modified from Danišík et al. [37]. (b) Simplified tectonic map of western and central Turkey with sample locations indicated by red star (samples 2023 and 2021), modified from Cao and Jung [10] and Davis and Whitney [34]. CACC: Central Anatolian crystalline complex; CAFZ: Central Anatolian fault zone; and NAF: North Anatolian fault. (c) Outcrop of Monte Pinatelle in Alpine Corsica. The blueschist shows a well-developed foliation. (d) Outcrop of the Halilbağ 1 area in the Sivrihisar Massif, in the Tavşanlı Zone. The blueschist exhibits compositional layering and foliation. Hammer provided for scale in subfigures (c,d).

\section{Methods}

Foliation is determined by parallel alignment of glaucophane, lawsonite, and white mica, and compositional layering of minerals. The lineation of the samples is defined by the shape preferred orientations of the lawsonite and glaucophane [38], and thin sections were made in the $\mathrm{x}-\mathrm{z}$ plane ( $\mathrm{x}$ : parallel to the lineation; $\mathrm{z}$ : normal to the foliation). The thin sections were polished with diamond paste and colloidal silica $(0.06 \mu \mathrm{m})$ and coated with carbon to avoid charging in the scanning electron microscope. Electron backscatter diffraction (EBSD) analysis, utilized to measure the CPOs of lawsonite and glaucophane, was performed in the $\mathrm{x}-\mathrm{z}$ plane of the samples utilizing Aztec software (Version 4.3, Oxford Instruments, Abingdon, UK) with a symmetry detector attached to a field emission scanning electron microscope (JSM 7100F, JEOL, Tokyo, Japan) at the School of Earth and Environmental Sciences at Seoul National University, Korea. The system was operated at a $20 \mathrm{kV}$ acceleration voltage and a $25 \mathrm{~mm}$ working distance. The lawsonite and glaucophane EBSD patterns were automatically indexed by mapping the sample with step sizes ranging from $\sim 1.2-3.0 \mu \mathrm{m}$, which were at least 10 times smaller than the average grain size of the samples. To prevent misinterpretation of the original data, the raw EBSD data was postcleaned utilizing Aztec software (Oxford Instruments) in three steps: (1) wild spikes with a 
pixel size were removed, (2) zero solution pixels that neighbor six pixels with solutions were eliminated, and (3) Step 1 was repeated.

The procedure to remove twins in lawsonite for plotting the CPOs is described as follows: Twin boundaries having a [001] rotation axis with a $67^{\circ}$ misorientation angle and a $5^{\circ}$ deviation were automatically disregarded as grain boundaries in EBSD orientation maps using Channel 5 software (Version 5.12.74.0). Then, the crystallographic orientation representing each grain was determined by the mean orientation of the lawsonite grains. This procedure was reiterated consistently for all grains in all samples. The lawsonite CPO with and without twins and glaucophane $\mathrm{CPO}$ were plotted in a pole figure as one point per grain to avoid introducing a bias by the large grains [39]. The misorientation index [40] was calculated to determine the CPO strength of the minerals.

The seismic velocity and anisotropy of the P- and S-waves of lawsonite were calculated utilizing the CPO, crystal density, and elastic constants of lawsonite [41], with a modified crystallographic reference [9]. They were calculated for glaucophane [42] utilizing a FORTRAN software program [43]. The seismic velocity and anisotropy of lawsonite and whole rocks were calculated for samples with and without twins. To calculate the seismic velocity and anisotropy in the absence of twins in lawsonite, narrow twin areas in lawsonite grains were removed manually in EBSD orientation maps using HKL Channel 5 Tango software. The choice of narrow twin removal in lawsonite was consistent for all samples. All point-per-grain crystallographic orientation data of lawsonite and glaucophane were used for accurate seismic properties with and without twins [39]. The seismic properties of the whole rocks were calculated utilizing the normalized volume fraction of the major minerals as lawsonite and glaucophane (Table 1). The normalized volume proportions of lawsonite and glaucophane were based on the mineral fractions from the large area EBSD mapping. Minor minerals such as garnet, omphacite, titanite, quartz, phengite, and epidote were ignored in the calculations.

Table 1. Modal composition, twin frequency, and CPO strength of samples.

\begin{tabular}{|c|c|c|c|c|c|c|c|c|}
\hline \multirow{2}{*}{ Sample } & \multirow{2}{*}{ Location } & \multicolumn{2}{|c|}{ Major Minerals ${ }^{1}$} & \multirow{2}{*}{$\begin{array}{l}\text { Grain Size } \\
(\mu \mathrm{m})^{2}\end{array}$} & \multirow{2}{*}{$\begin{array}{c}\text { Twin } \\
\text { Frequency } \\
3\end{array}$} & \multirow{2}{*}{$\begin{array}{c}\text { Fraction of } \\
\text { Twinned Area (\%) }\end{array}$} & \multicolumn{2}{|c|}{ CPO Strength ${ }^{4}$} \\
\hline & & Lws (\%) & Gln (\%) & & & & $\mathbf{M}_{1}$ & $\mathbf{M}_{2}$ \\
\hline 3034 & Corsica & 37 & 63 & 104 & High & 31.4 & 0.15 & 0.17 \\
\hline 3033 & Corsica & 45 & 55 & 29 & Middle & 15.5 & 0.23 & 0.24 \\
\hline 2023 & Sivrihisar & 43 & 57 & 106 & Low & 12.9 & 0.12 & 0.09 \\
\hline 2021 & Sivrihisar & 53 & 47 & 38 & Very low & 0.6 & 0.078 & 0.080 \\
\hline
\end{tabular}

${ }^{1}$ Normalized volume proportions of major minerals (lawsonite and glaucophane) are based on the mineral fractions by large area EBSD mapping. ${ }^{2}$ Grain size is determined as the average length of the maximum Feret diameters [44] of the lawsonite grains. ${ }^{3}$ Twin frequency is determined by the number of twins per length in lawsonite. The fraction of the twinned area (area of the twinned domain) is determined by large-area EBSD mapping. ${ }^{4} \mathrm{M} 1$ and $\mathrm{M} 2$ represent the misorientation index of lawsonite with and without twins, respectively. Lws: lawsonite; Gln: glaucophane; CPO: crystal preferred orientation.

\section{Results}

\subsection{Microstructures}

Four representative lawsonite blueschist samples collected from Alpine Corsica at Monte Pinatelle and the Halilbağ 1 area in the Tavşanlı Zone were studied. The major minerals in the blueschists were lawsonite and glaucophane, and the minor minerals were garnet, omphacite, titanite, quartz, phengite, and epidote. Blueschists from Alpine Corsica showed higher phengite and omphacite content than those from the Halilbağ $\breve{a r e a}^{\text {. All }}$ samples showed high volume proportions of lawsonite (Table 1) in the 37-53\% range.

The lawsonite crystals were primarily euhedral or subhedral, and the glaucophane crystals exhibited needle shapes (Figures 2 and 3, respectively). The samples were characterized by well-developed non-folded foliation and mineral stretching lineation (Figure 2a-d,g,h), except for sample 2023 (Figure 2e,f). Sample 3034 from Monte Pinatelle contained coarsegrained lawsonite, whereas sample 3033 contained fine-grained lawsonite (Table 1). Sample 2023 from the Halilbağ1 area contained coarse-grained lawsonite, whereas sample 2021 
contained fine-grained lawsonite. Samples 3034 and 3033 showed high and medium frequencies of twins in the lawsonite, respectively (Figure 3a,b), and samples 2023 and 2021 exhibited low and very low frequencies of twins, respectively (Figure $3 c, d$ ).
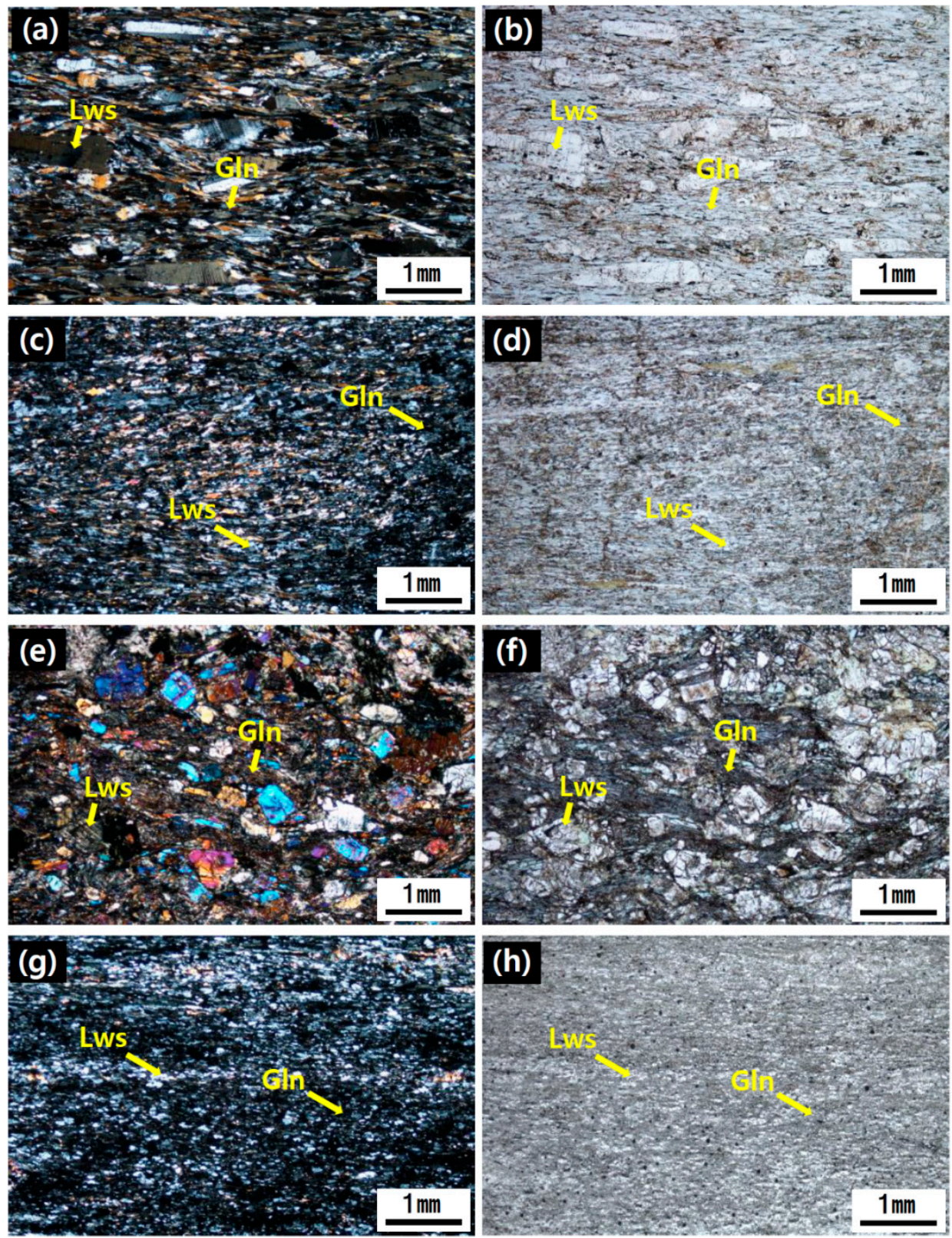

Figure 2. Photomicrographs of lawsonite blueschist samples from (a-d) Alpine Corsica and (e-h) the Sivrihisar Massif $(\mathbf{a}, \mathbf{c}, \mathbf{e}, \mathbf{g})$ are in cross-polarized light, and (b,d,f,h) are in plane-polarized light). Photomicrographs are from thin sections prepared in the $x-z$ plane. (a,b) Sample 3034, characterized by coarse-grained lawsonite. (c,d) Sample 3033, characterized by fine-grained lawsonite. (e,f) Sample 2023, characterized by coarse-grained lawsonite. (g,h) Sample 2021, characterized by fine-grained lawsonite. According to the consistent arrangement of needle-shaped glaucophanes parallel to the lineation and short direction of lawsonite normal to the foliation, samples are considered to have been deformed in a non-coaxial mode. Lws: lawsonite; Gln: glaucophane. 

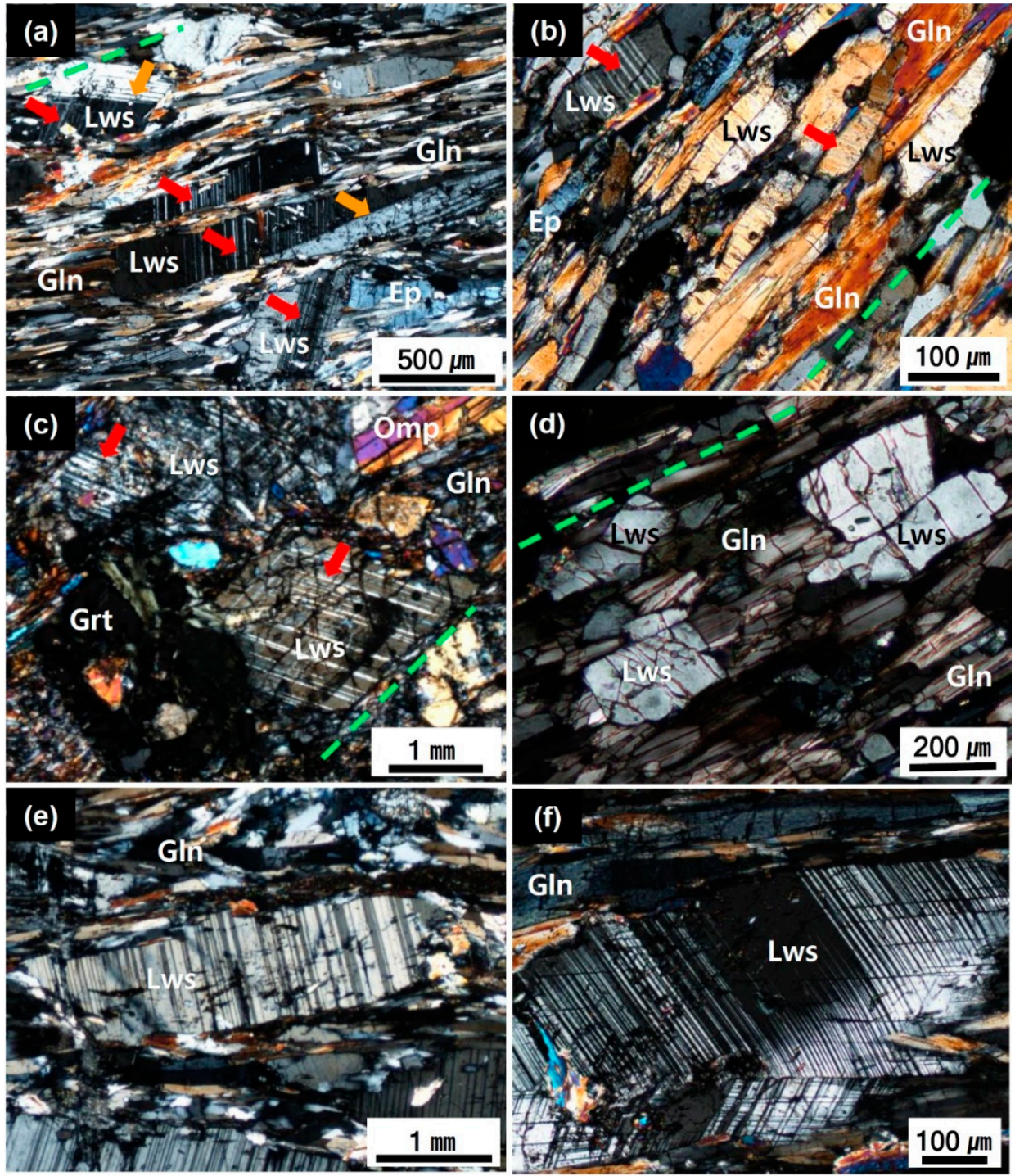

Figure 3. Enlarged photomicrographs of lawsonite blueschist samples. All photos are from thin sections in the $\mathrm{x}-\mathrm{z}$ plane in cross-polarized light. (a) High lawsonite twin frequency (sample 3034); (b) medium lawsonite twin frequency (sample 3033); (c) low lawsonite twin frequency (sample 2023); (d) very low lawsonite twin frequency and some fracturing in lawsonite (sample 2021); (e) representative polysynthetic twin in lawsonite (sample 3034); and (f) representative deformation twin with curved textures in lawsonite (sample 3034). Some crossed twins can be observed as the second generation of twins, which are horizontal in (f). The green dashed lines indicate the foliations of the samples, and red and orange arrows denote the polysynthetic and deformation twins, respectively. Lws: lawsonite; Gln: glaucophane; Grt: garnet; Omp: omphacite; Ep: epidote.

Examples of polysynthetic and deformation twins are shown in Figure 3e,f. In lawsonite, polysynthetic twinning showed repeated contacts on $\{110\}$ planes, whereas deformation twinning exhibited curved textures and crossing behaviors on $\{110\}$ planes. Polysynthetic twins in lawsonites were also shown in the EBSD phase and grain maps in Figure 4 . The $\{110\}$ twin was detected in lawsonite, where twin boundaries were shown as red lines in Figure $4 \mathrm{~b}$ and indicated by white arrows in the enlarged EBSD grain map in Figure 4c. The EBSD phase map (Figure $4 \mathrm{~b}$ ) showed $\{110\}$ twin planes with a $67^{\circ}$ rotation of lawsonite, indicating that the red boundaries are not lattice bending or subgrains but twin boundaries in lawsonite. 


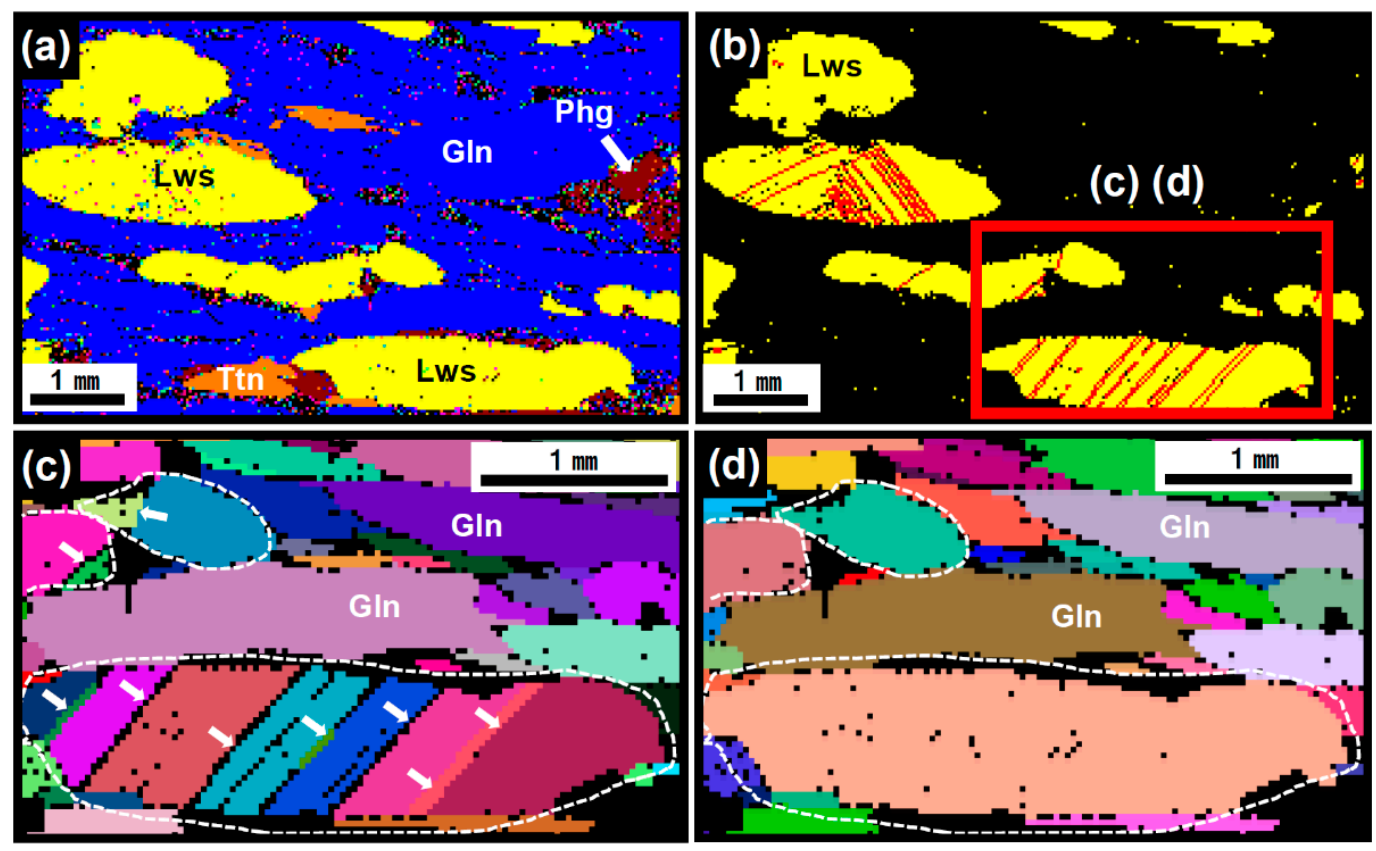

Figure 4. (a) Electron backscatter diffraction (EBSD) phase and grain maps of sample 3034. (b) EBSD phase map of sample 3034 showing the twin boundaries (red lines) in the lawsonite. Only lawsonite grains are shown (yellow color). Two sets of polysynthetic twins, which are almost perpendicular to each other, are shown in lawsonite. (c) EBSD grain map magnified from the EBSD phase map in Figure 4b. White arrows indicate the twin boundaries in lawsonite. (d) EBSD grain map without twins magnified from the EBSD phase map in Figure 4b. The twin boundaries in the lawsonite were eliminated using Aztec Software. The white dashed lines denote the true grain boundary of lawsonite. Lws: lawsonite; Gln: glaucophane; Phg: phengite; Ttn: titanite.

\subsection{CPOs of Lawsonite and Glaucophane}

\subsubsection{CPOs and CPO Strength of Lawsonite}

The CPOs of lawsonite with and without twins in the samples are presented in Figure 5. The deformed samples with and without twins showed that the maxima of the [001] axes of lawsonite are aligned subnormal to the foliation, and the [100] and [010] axes are aligned subparallel to the foliation (Figure 5a-c,e-g), except for sample 2021 (Figure 5d,h). Sample 2021 showed a weak lawsonite CPO, where the [010] axes of lawsonite were strongly aligned subparallel to the lineation, and the [100] axes were aligned as a weak girdle subnormal to the lineation. There were some differences in the lawsonite CPO strength depending on the fraction (size) of the twinned area (the area of the twinned domain) in the sample (Table 1 and Figure 5). The CPO strength of lawsonite in the samples with twins (twin fraction $>15 \%$ ) was relatively low $(\mathrm{M}=0.15-0.23)$ compared to that in the samples without twins $(\mathrm{M}=0.17-0.24)$ (Figure 5). Sample 2021, which was characterized by a very low twin fraction $(0.6 \%)$, showed the almost same CPO strength of lawsonite with twins $(\mathrm{M}=0.078)$ and lawsonite without twins $(\mathrm{M}=0.080)$. 


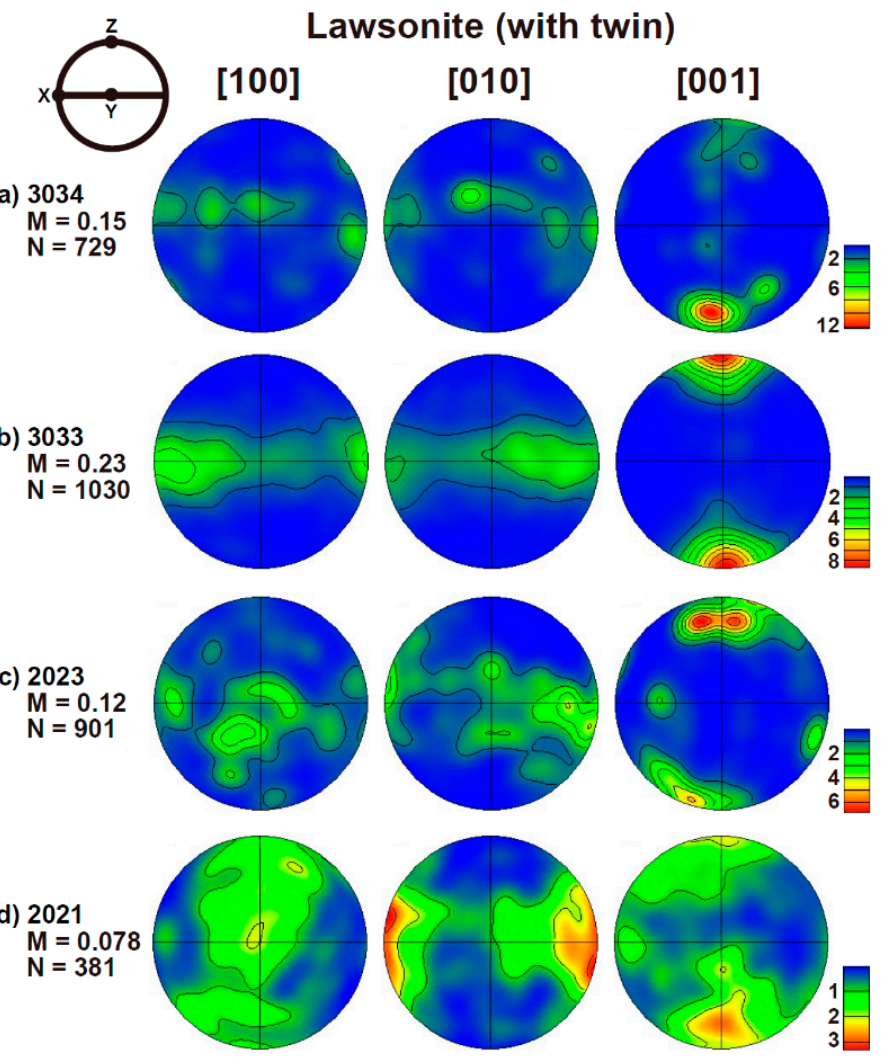

\section{Lawsonite (without twin)}

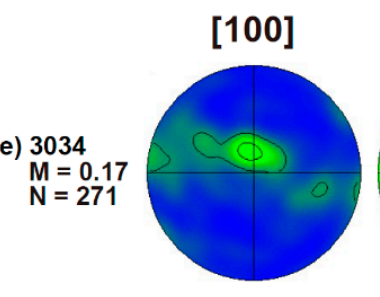

[010]
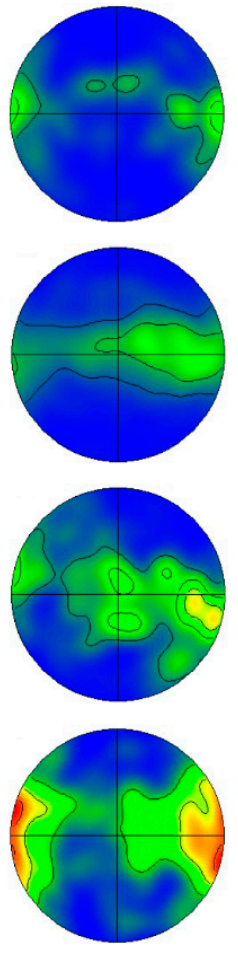

[001]
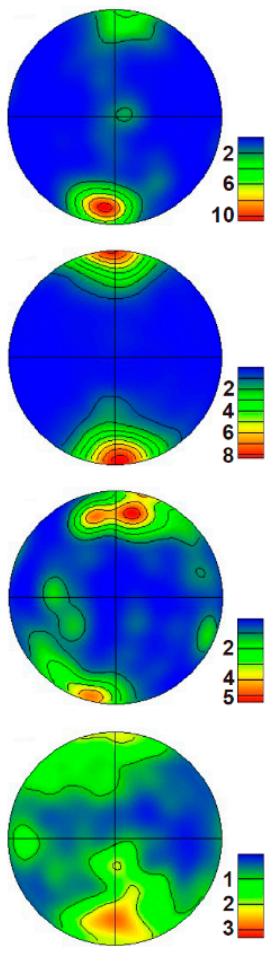

Figure 5. (a-h) Pole figures of lawsonite depending on the existence of twins are presented with a lower hemisphere equal-area projection. The $\mathrm{x}$ and $\mathrm{z}$ directions correspond to the lineation and direction normal to the foliation, respectively. A $20^{\circ}$ half-scatter width and a $5^{\circ}$ cluster size are used. Contours represent the $\mathrm{CPO}$ strength, and multiples of uniform distribution (m.u.d.) are shown as color bars. The higher the number of the bar, the higher is the $\mathrm{CPO}$ strength. M: misorientation index; $\mathrm{N}$ : number of grains. 


\subsubsection{CPO of Glaucophane}

The glaucophane CPOs are presented in Figure 6. The maxima of the glaucophane [001] axes were aligned subparallel to the lineation, and the maxima of the (110) poles and [100] axes were aligned subnormal to the foliation (Figure $6 a, b, d)$. The (010) poles showed a high concentration subnormal to the lineation near the center of the pole figure, except for sample 2023, which showed weak girdle distributions of the (110) and (010) poles subnormal to the lineation (Figure $6 \mathrm{c}$ ).

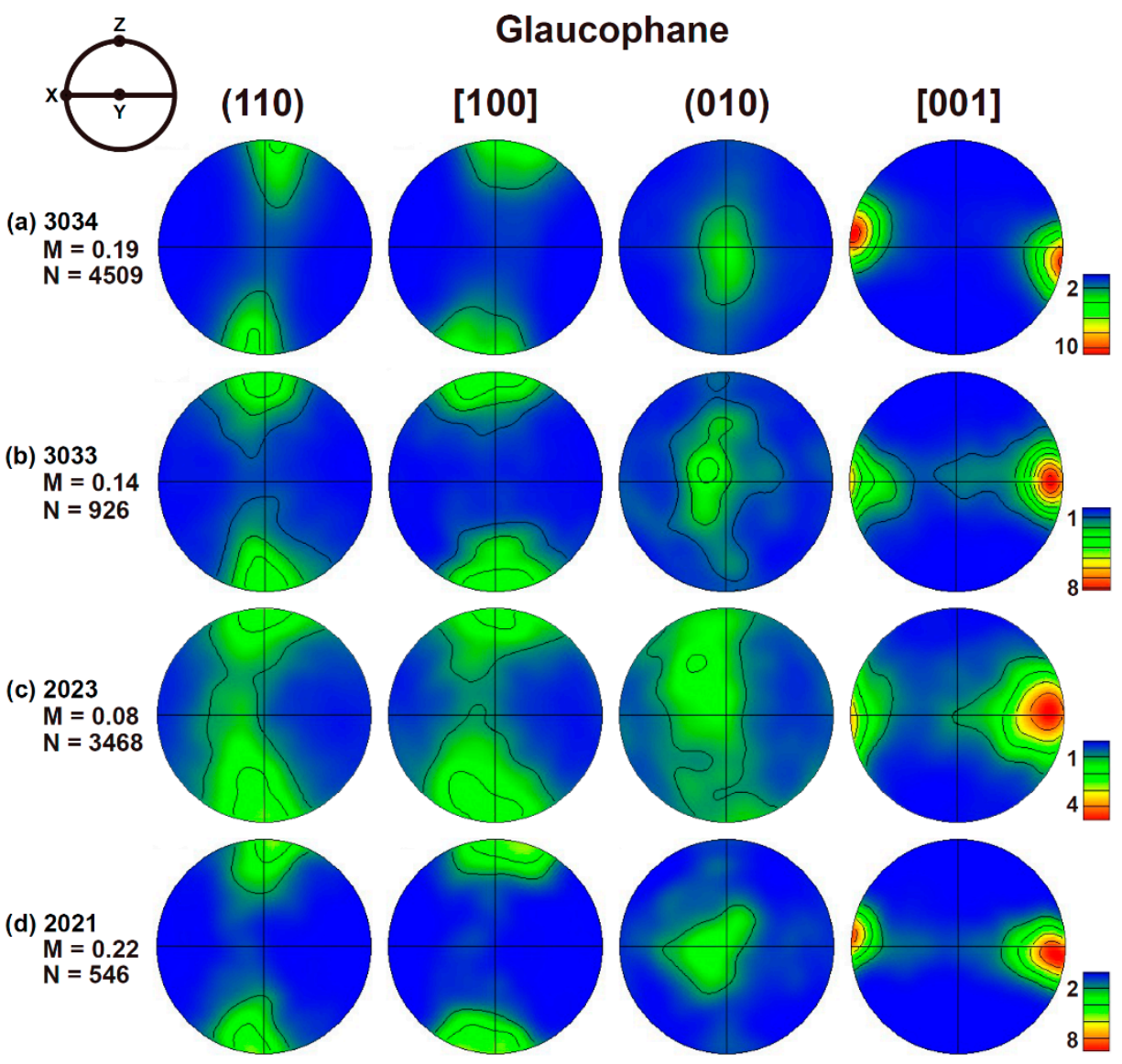

Figure 6. (a-d) Pole figures of glaucophane. The $x$ and $z$ directions correspond to the lineation and direction normal to the foliation, respectively. A $20^{\circ}$ half-scatter width and a $5^{\circ}$ cluster size are used. Contours represent the CPO strength, and multiples of uniform distribution (m.u.d.) are shown as color bars. The higher the number of the bar, the higher is the CPO strength. M: misorientation index; $\mathrm{N}$ : number of grains.

\subsection{Seismic Velocity and Anisotropy of Minerals and Whole Rocks}

The seismic velocities and anisotropies of lawsonite aggregates with and without twins are presented in Figure 7. For the lawsonite aggregate with twins, the P-wave seismic anisotropy $(\mathrm{AVp}$ ) ranged from $5.1 \%$ to $12.6 \%$, and the maximum S-wave seismic anisotropy (max AVs) ranged from $10.15 \%$ to $20.87 \%$ (Figure $7 \mathrm{a}-\mathrm{d}$ ). For the lawsonite aggregate without twins, AVp and max AVs ranged from $5.1 \%$ to $13.0 \%$ and from $10.12 \%$ to $22.64 \%$, respectively (Figure $7 \mathrm{e}-\mathrm{h}$ ). Therefore, $\mathrm{AVp}$ and max AVs are lower in lawsonite aggregates with twins, except for sample 2021, which shows a very low frequency of lawsonite twinning (Figure $7 \mathrm{~d}, \mathrm{~h}$ ). The direction of the P-wave velocity is subnormal to the foliation regardless of the existence of twins. 


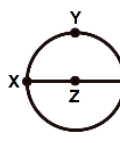

(a) 3034

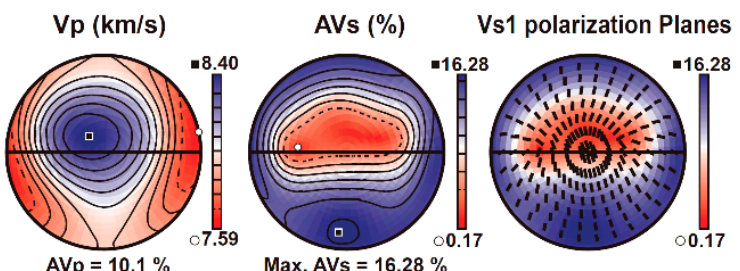

(b) 3033
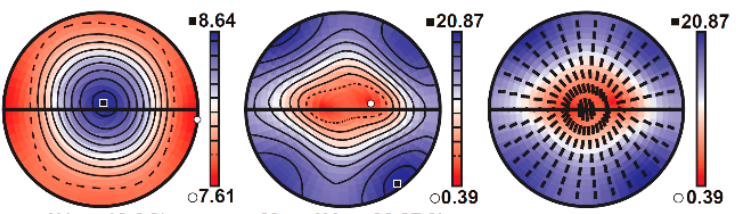

(c) 2023

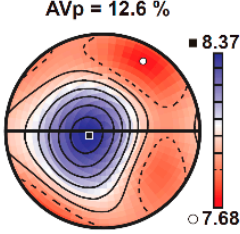

Max. AVs $=20.87 \%$
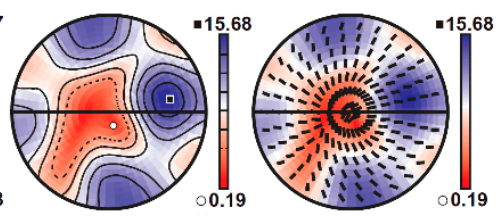

(d) 2021

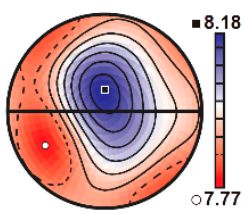
Max. AVs $=15.68 \%$

$\mathrm{AVp}=5.1 \%$

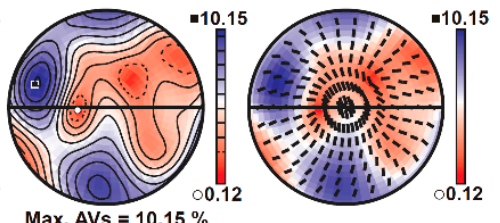

Lawsonite (without twin)

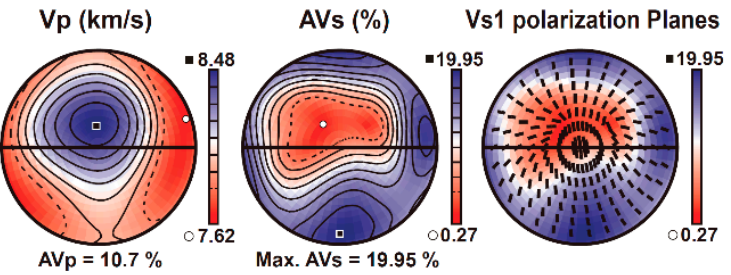

(f) 3033

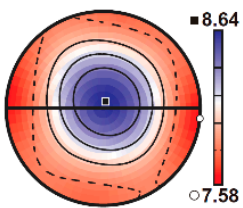

(e) 3034

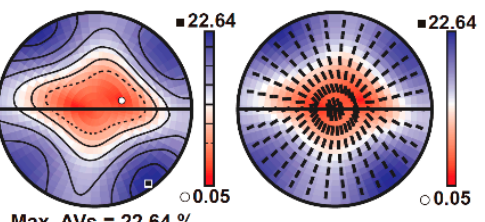

(g) 2023

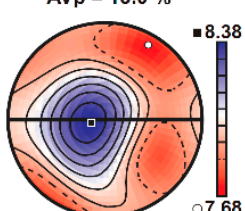

Max. AVs = $22.64 \%$

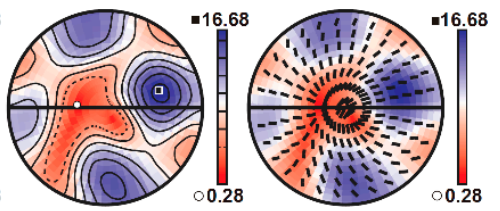

(h) 2021

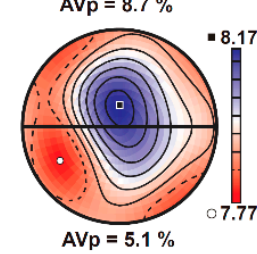

Max. AVs $=16.68 \%$

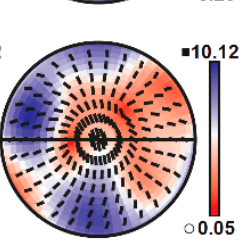

Figure 7. (a-h) Seismic properties of lawsonite with and without twins. The poles are presented with a lower hemisphere equal-area projection. The $\mathrm{x}$ and $\mathrm{z}$ directions correspond to the lineation and direction normal to the foliation, respectively. Vp: P-wave velocity; AVp: anisotropy of P-wave velocity; AVs: anisotropy of S-wave velocity; max AVs: maximum anisotropy of S-wave velocity; Vs1: fast $S$-wave velocity. 
The seismic anisotropy of the glaucophane aggregates is presented in Figure 8. The $\mathrm{AVp}$ and max $\mathrm{AVs}$ of glaucophane range from $13.0 \%$ to $25.1 \%$ and from $6.33 \%$ to $14.48 \%$, respectively, and the direction of the P-wave velocity is aligned subparallel to the lineation (Figure 8a-d).

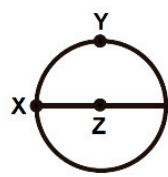

(a) 3034
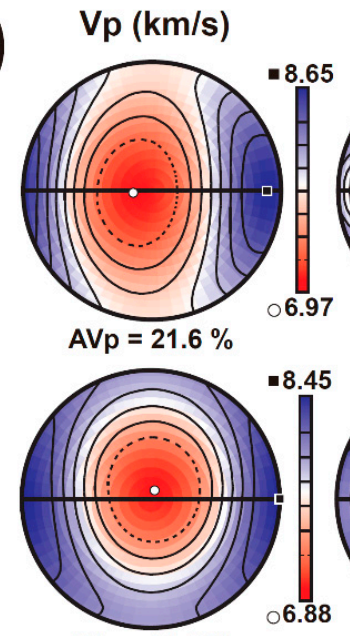

Glaucophane

(b) 3033
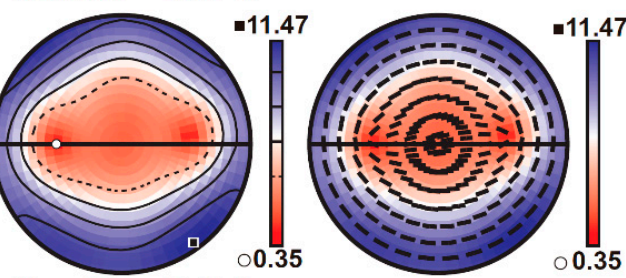

Max. AVs $=11.47 \%$

(c) 2023
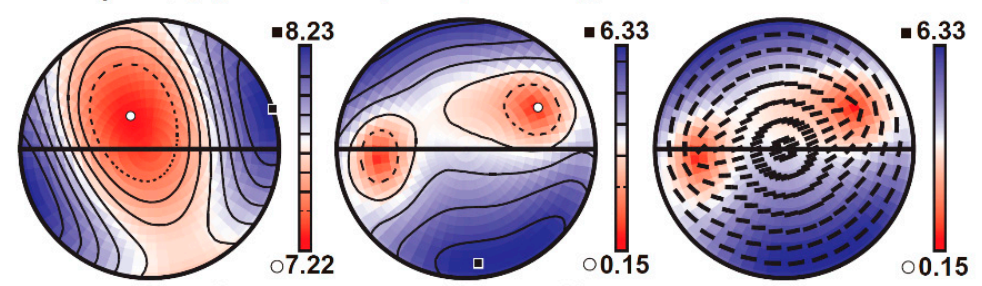

$A V p=13.0 \%$

Max. AVs $=6.33 \%$
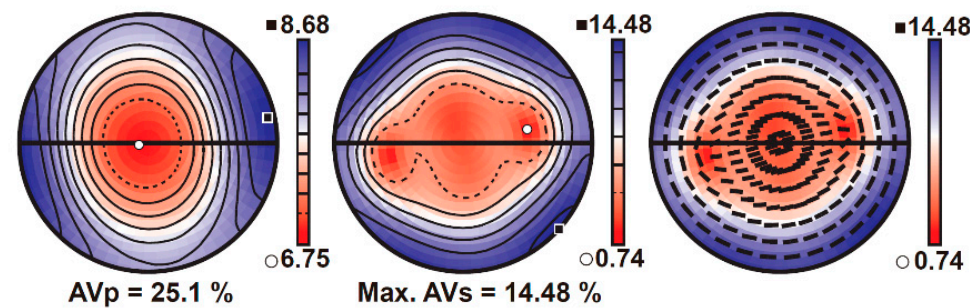

Max. AVs = $14.48 \%$

Figure 8. (a-d) Seismic properties of glaucophane. The poles are presented with a lower hemisphere equal-area projection. The $\mathrm{x}$ and $\mathrm{z}$ directions correspond to the lineation and direction normal to the foliation, respectively. Vp: P-wave velocity; AVp: anisotropy of P-wave velocity; AVs: anisotropy of S-wave velocity; max AVs: maximum anisotropy of S-wave velocity; Vs1: fast S-wave velocity.

The seismic anisotropies of the whole rocks are presented in Figure 9. For whole rocks with lawsonite twins, $\mathrm{AVp}$ and max AVs vary from $4.3 \%$ to $9.5 \%$ and from $4.54 \%$ to $7.63 \%$, respectively (Figure 9a-d). For whole rocks without lawsonite twins, AVp and max AVs ranged from $4.3 \%$ to $9.5 \%$ and from $6.00 \%$ to $8.13 \%$, respectively (Figure $9 \mathrm{e}-\mathrm{h}$ ). Generally, $\mathrm{AVp}$ and max AVs increased in the samples without lawsonite twins, and the direction of the P-wave velocity was similar to that in glaucophane regardless of the existence of twins. 


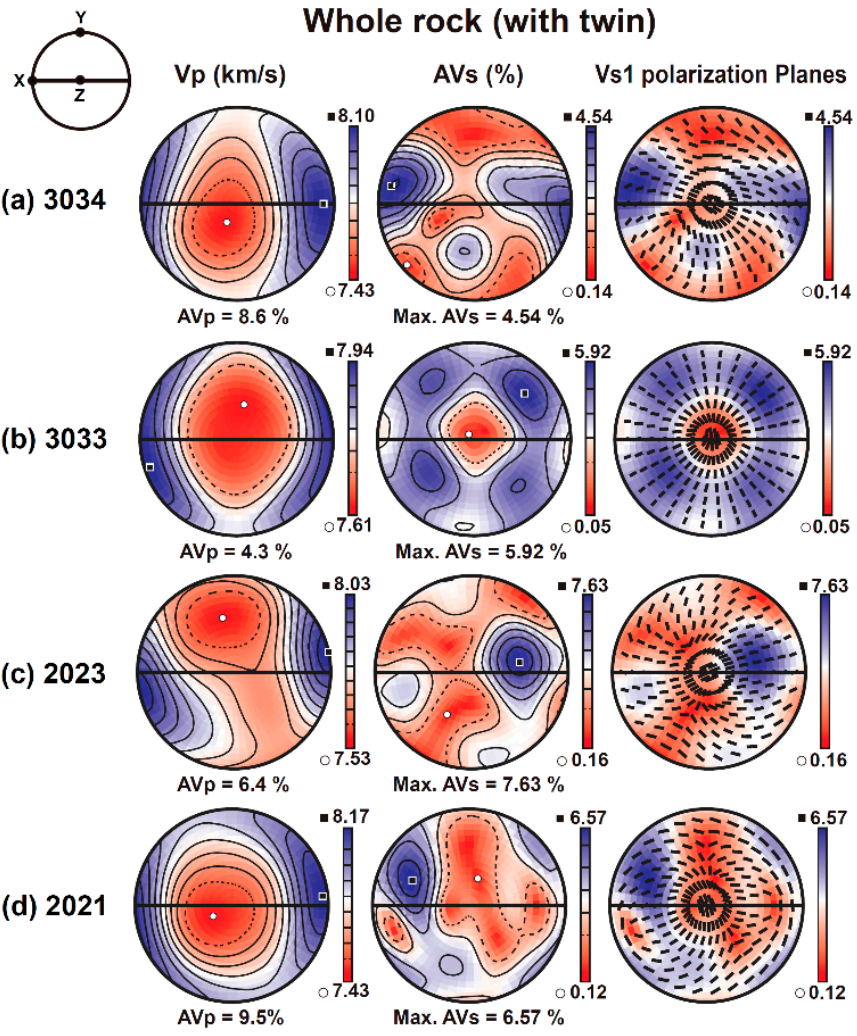

Whole rock (without twin)

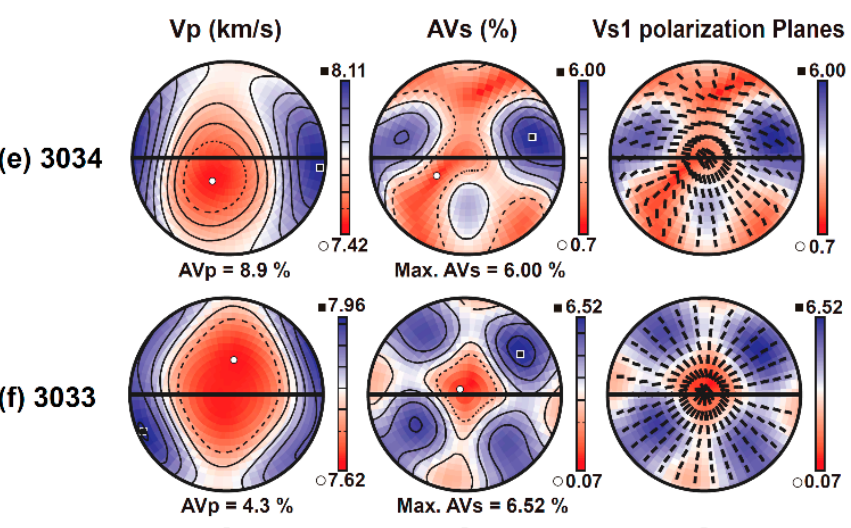

(g) 2023

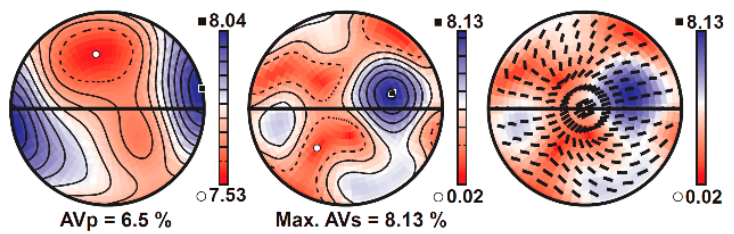

(h) 2021

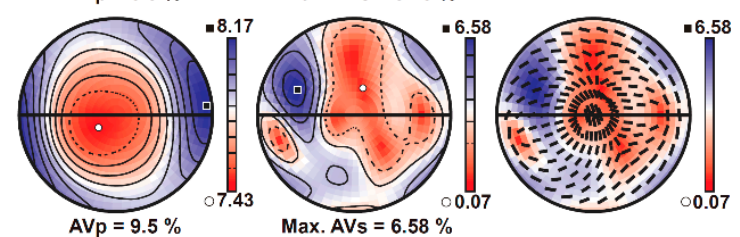

Figure 9. (a-h) Seismic properties of whole rocks with and without twins. The poles are presented with a lower hemisphere equal-area projection. The $\mathrm{x}$ and $\mathrm{z}$ directions correspond to the lineation and direction normal to the foliation, respectively. Vp: P-wave velocity; AVp: anisotropy of P-wave velocity; AVs: anisotropy of S-wave velocity; max AVs: maximum anisotropy of S-wave velocity; Vs1: fast S-wave velocity. 


\section{Discussion}

\subsection{CPO of Lawsonite and Effect of Twins on the CPO Strength of Lawsonite}

All the CPOs of lawsonite in deformed blueschists from Alpine Corsica and the Sivrihisar Massif are characterized by the maxima of the [001] axes aligned subnormal to the foliation regardless of twin existence and by [100] and [010] axes aligned subparallel to the foliation (Figure 5). These features are consistent with those of previous studies on blueschists and eclogites from the North Qilian suture zone in China [9], the Sivrihisar Massif in Turkey [10], the Diablo Range in California, USA [11], the southern Motagua fault zone in Guatemala [12], and the Kurosegawa Belt in Japan [45]. However, this study reveals that the $\mathrm{CPO}$ strength of lawsonite is reduced when considering the existence of twins in lawsonite. The CPO strength of lawsonite with twins is lower $(\mathrm{M}=0.078-0.23)$ than that of lawsonite without twins ( $M=0.080-0.24)$, except in sample 2023 (Figure 5). Sample 2023 shows a higher CPO strength of lawsonite with twins than without twins $(\mathrm{M}=0.12$ and 0.09 , respectively). This may be related to the scattered distribution of the [001] axes that are partly aligned subparallel to the lineation.

Figure 10 illustrates the influence of lawsonite twins on the CPO of lawsonite in a single grain. The $\{110\}$ twins in the grain are easily identified in the inverse pole figure orientation map (Figure 10a), and the misorientation angles of the twin boundaries are $67^{\circ}$ (Figure 10b). This angle is large enough to diffuse the [100] and [010] axes of lawsonite, but not the [001] axis, which is the rotation axis of the $\{110\}$ twin (Figure 10c). The existence of lawsonite twinning thus produces a weak CPO on the [100] and [010] axes (Figure 10c,d), but a strong alignment of the [001] axes (Figure 5a,b,e,f). Therefore, lawsonite twinning could be one of the mechanisms that weakens the CPO strength of lawsonite. However, we do not know the exact origin of twins in lawsonite. There is a lack of information on the pressure, temperature, and differential stress conditions in which lawsonite twins occur.

(a)

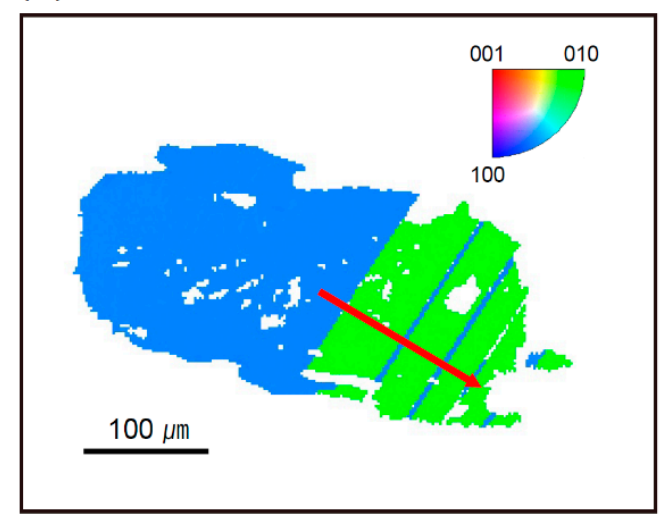

(c)

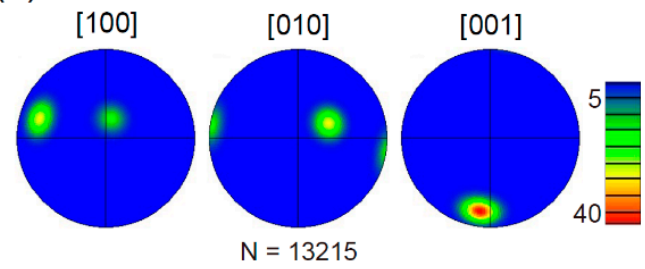

(b)

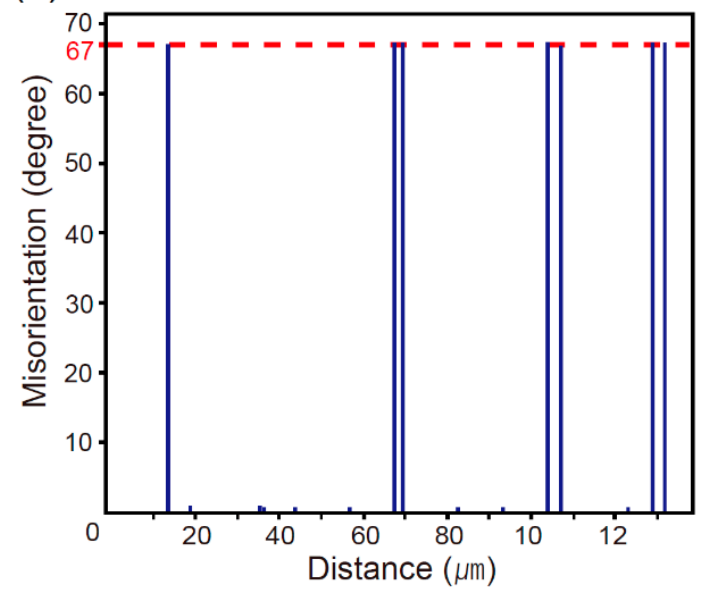

(d)

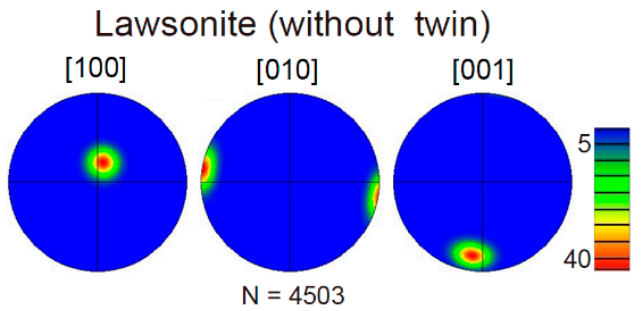

Figure 10. (a) Inverse pole figure orientation map parallel to the lineation direction of a single lawsonite grain; (b) misorientation line profile of the red line in Figure 10a; pole figures of the single lawsonite grain in Figure 10a (c) with twins and (d) without twins. Pole figures were produced using all points per grain. A $20^{\circ}$ half-scatter width and a $5^{\circ}$ cluster size were utilized. N: number of data points. 


\subsection{Effect of Lawsonite Twinning on Seismic Anisotropy in Subducting Oceanic Crust}

The seismic anisotropy of lawsonite reduces the $\mathrm{AVp}$ and $\mathrm{AVs}$ by up to $0.60 \%$ and $3.67 \%$, respectively, when lawsonite twinning is taken into account (Table 2). Notably, $\mathrm{S}$-wave anisotropy is significantly greater than P-wave anisotropy, possibly due to the seismic anisotropy of the lawsonite single crystal [41] which shows a much larger max AVs value (65\%) than the AVp value (24\%) [9]. The effect of lawsonite twinning on the seismic anisotropy of whole-rock blueschist is also presented in Table 2. The seismic anisotropy of the whole rock also reduces the $\mathrm{AVp}$ and $\mathrm{AVs}$ by up to $0.30 \%$ and $1.46 \%$, respectively, when lawsonite twinning is considered. Lawsonite twinning has only a minor effect on the $\mathrm{P}$-wave anisotropy, but a relatively larger effect on the S-wave anisotropy of lawsonite and whole rock. The seismic anisotropy reduces with increasing area of twinned domain in lawsonite (Tables 1 and 2). For example, the difference of the max AVs of lawsonite with and without twins is very small for sample 2021, which has a very small area of twinned domain; however, the difference of max AVs of lawsonite is $3.67 \%$ for sample 3034 , which has a large area of twinned domain.

Table 2. Seismic anisotropy of lawsonite and whole-rock.

\begin{tabular}{cccccc}
\hline \multirow{2}{*}{ Sample } & \multirow{2}{*}{ Twin } & \multicolumn{2}{c}{ Lawsonite } & \multicolumn{2}{c}{ Whole Rock } \\
\cline { 3 - 6 } & & AVp (\%) & Max AVs (\%) & AVp (\%) & Max AVs (\%) \\
\hline \multirow{2}{*}{3034} & with twin & 10.10 & 16.28 & 8.60 & 4.54 \\
& without twin & 10.70 & 19.95 & 8.90 & 6.00 \\
\hline \multirow{2}{*}{3033} & $-0.60 \%$ & $-3.67 \%$ & $-0.30 \%$ & $-1.46 \%$ \\
\hline \multirow{2}{*}{2023} & 12.60 & 20.87 & 4.30 & 5.92 \\
& with twin & 13.00 & 22.64 & 4.30 & 6.52 \\
\hline \multirow{2}{*}{2021} & without twin & $-0.40 \%$ & $-1.77 \%$ & $0 \%$ & $-0.60 \%$ \\
& with twin & 8.50 & 15.68 & 6.40 & 7.63 \\
& without twin & 8.70 & 16.68 & 6.50 & 8.13 \\
\hline \multirow{2}{*}{2} & $-0.20 \%$ & $-1.00 \%$ & $-0.10 \%$ & $-0.50 \%$ \\
\hline \multirow{2}{*}{ with twin } & 5.10 & 10.15 & 9.50 & 6.57 \\
& without twin & 5.10 & 10.12 & 9.50 & 6.58 \\
\hline
\end{tabular}

${ }^{1}$ Change of seismic anisotropy of lawsonite and whole rock with twin compared to that of lawsonite and whole rock without twin. Anisotropy of $\mathrm{P}$-wave $(\mathrm{AVp})=200 \times\left(\mathrm{Vp}_{\max }-\mathrm{Vp}_{\min }\right) /\left(\mathrm{Vp}_{\max }+\mathrm{Vp}_{\min }\right)$, and anisotropy of $\mathrm{S}$-wave $(\mathrm{AVs})=200 \times(\mathrm{Vs} 1-\mathrm{Vs} 2) /(\mathrm{Vs} 1+\mathrm{Vs} 2)$. Max AVs: maximum anisotropy of S-wave velocity.

In Figure 10, we manually removed the blue part (narrow area) of the twin in the lawsonite grain. This is because most of the twins in lawsonite in the studied samples are observed as narrow areas (for example, see Figure 3). The choice of twin removal may have an influence on the resulting $\mathrm{CPO}$ and seismic anisotropy of lawsonite. According to our study, the seismic anisotropy reduces with increasing area of the twinned domain in lawsonite. If wide areas of twins are removed in lawsonite, the area of the twinned domain in the sample would become larger, resulting in a large effect of twins in lawsonite on the reduction of seismic anisotropy. Thus, the choice of narrow twin removal in this study has produced the minimum effect of twins on the reduction of seismic anisotropy.

Based on these findings, the existence of twins in lawsonite can induce the reduction of seismic anisotropy in blueschist, particularly S-wave anisotropy, which is attributed to the ability of the $\{110\}$ twin to weaken the lawsonite CPO strength (i.e., weak alignment of the [100] and [010] axes) (Figure 5). The CPO strength, along with other factors, including rock type and interactions between the CPOs of different minerals, can lead to a change in the seismic anisotropy in lawsonite blueschist [10]. This study clearly shows that lawsonite twinning can be an important factor in determining the seismic anisotropy of lawsonitebearing rocks if the area of the twinned domain in lawsonite is large. 
Lawsonite twinning has also been reported in natural lawsonite eclogites [10,18]. As eclogite mainly consists of anhydrous minerals such as garnet and omphacite, it has a weaker seismic anisotropy than blueschist $[46,47]$. Therefore, the influence of lawsonite on the seismic anisotropy of eclogite is significant [12,13]. Lawsonite twinning can also produce seismic anisotropy reduction in lawsonite eclogite, particularly S-wave anisotropy. As lawsonite is prevalent in the subducting oceanic crust of cold subduction zones, lawsonite twinning can be important in determining seismic anisotropy.

\section{Conclusions}

The effect of lawsonite twinning on the CPO and seismic anisotropy of lawsonite and lawsonite blueschist was studied using lawsonite blueschists collected from Alpine Corsica and the Sivrihisar Massif. The results indicate that polysynthetic and deformation twins of lawsonite exist on the $\{110\}$ plane with the rotation of the [001] symmetry axis by $67^{\circ}$. The CPO of lawsonite with twins is weakened due to the scattered distribution of the [100] and [010] axes. Lawsonite twinning induces a substantial reduction in the maximum S-wave anisotropy (max AVs) by up to $3.67 \%$ and $1.46 \%$ for lawsonite and whole rock, respectively, and a minor reduction of the $\mathrm{P}$-wave anisotropy ( $\mathrm{AVp}$ ) by up to $0.6 \%$ and $0.3 \%$ for lawsonite and whole rock, respectively. Considering the distribution of lawsonite in blueschist and eclogite in cold subduction zones, lawsonite twinning needs to be taken into account in determining seismic anisotropy.

Author Contributions: Conceptualization, S.C and H.J.; methodology, S.C.; software, S.C.; validation, S.C., O.F., G.T., A.I.O., and H.J.; formal analysis, S.C.; investigation, S.C.; resources, O.F., G.T., A.I.O., and H.J.; data curation, S.C.; writing —original draft preparation, S.C.; writing-review and editing, O.F., G.T., A.I.O., and H.J.; visualization, S.C.; supervision, H.J.; project administration, H.J.; funding acquisition, H.J. All authors have read and agreed to the published version of the manuscript.

Funding: This research was funded by the Mid-Career Research Program through the National Research Foundation of Korea (NRF: 2020R1A2C2003765) and the Korea Meteorological Administration Research Development Program (KMI2019-00110) to H.J. G.T. and A.I.O. gratefully acknowledge financial support from Turkish Academy of Sciences for field work.

Data Availability Statement: Not applicable.

Conflicts of Interest: The authors declare no conflict of interest.

\section{References}

1. Savage, M. Seismic anisotropy and mantle deformation: What have we learned from shear wave splitting? Rev. Geophys. 1999, 37, 65-106. [CrossRef]

2. Long, M.D.; Silver, P.G. The subduction zone flow field from seismic anisotropy: A global view. Science 2008, 319, 315-318. [CrossRef]

3. Long, M.D. Constraints on Subduction Geodynamics from Seismic Anisotropy. Rev. Geophys. 2013, 51, 76-112. [CrossRef]

4. Zhao, D.; Yu, S.; Liu, X. Seismic anisotropy tomography: New insight into subduction dynamics. Gondwana Res. 2016, 33, 24-43. [CrossRef]

5. Healy, D.; Reddy, S.M.; Timms, N.E.; Gray, E.M.; Brovarone, A.V. Trench-parallel fast axes of seismic anisotropy due to fluid-filled cracks in subducting slabs. Earth Planet. Sci. Lett. 2009, 283, 75-86. [CrossRef]

6. Wang, J.; Zhao, D. Mapping P-wave anisotropy of the Honshu arc from Japan Trench to the back-arc. J. Asian Earth Sci. 2010, 39, 396-407. [CrossRef]

7. Jung, H. Crystal preferred orientations of olivine, orthopyroxene, serpentine, chlorite, and amphibole, and implications for seismic anisotropy in subduction zones: A review. Geosci. J. 2017, 21, 985-1011. [CrossRef]

8. Almqvist, B.S.; Mainprice, D. Seismic properties and anisotropy of the continental crust: Predictions based on mineral texture and rock microstructure. Rev. Geophys. 2017, 55, 367-433. [CrossRef]

9. Cao, Y.; Jung, H.; Song, S. Microstructures and petro-fabrics of lawsonite blueschist in the North Qilian suture zone, NW China: Implications for seismic anisotropy of subducting oceanic crust. Tectonophysics 2014, 628, 140-157. [CrossRef]

10. Cao, Y.; Jung, H. Seismic properties of subducting oceanic crust: Constraints from natural lawsonite-bearing blueschist and eclogite in Sivrihisar Massif, Turkey. Phys. Earth Planet. Inter. 2016, 250, 12-30. [CrossRef]

11. Kim, D.; Katayama, I.; Michibayashi, K.; Tsujimori, T. Deformation fabrics of natural blueschists and implications for seismic anisotropy in subducting oceanic crust. Phys. Earth Planet. Inter. 2013, 222, 8-21. [CrossRef] 
12. Kim, D.; Wallis, S.; Endo, S.; Ree, J.-H. Seismic properties of lawsonite eclogites from the southern Motagua fault zone, Guatemala. Tectonophysics 2016, 677-678, 88-98. [CrossRef]

13. Park, M.; Jung, H. Relationships Between Eclogite-Facies Mineral Assemblages, Deformation Microstructures, and Seismic Properties in the Yuka Terrane, North Qaidam Ultrahigh-Pressure Metamorphic Belt, NW China. J. Geophys. Res. Solid Earth 2019, 124, 13168-13191. [CrossRef]

14. Iizuka-Oku, R.; Soustelle, V.; Miyajima, N.; Walte, N.P.; Frost, D.J.; Yagi, T. Experimentally deformed lawsonite at high pressure and high temperature: Implication for low velocity layers in subduction zones. Phys. Earth Planet. Inter. 2019, $295,106282$. [CrossRef]

15. Fornash, K.F.; Whitney, D.L.; Seaton, N.C.A. Lawsonite composition and zoning as an archive of metamorphic processes in subduction zones. Geosphere 2018, 15, 24-46. [CrossRef]

16. Whitney, D.L.; Fornash, K.F.; Kang, P.; Ghent, E.D.; Martin, L.; Okay, A.I.; Vitale Brovarone, A. Lawsonite composition and zoning as tracers of subduction processes: A global review. Lithos 2020, 370-371, 105636. [CrossRef]

17. Tsujimori, T.; Ernst, W.G. Lawsonite blueschists and lawsonite eclogites as proxies for palaeo-subduction zone processes: A review. J. Metamorph. Geol. 2014, 32, 437-454. [CrossRef]

18. Tamblyn, R.; Hand, M.; Morrissey, L.; Zack, T.; Phillips, G.; Och, D. Resubduction of lawsonite eclogite within a serpentinite-filled subduction channel. Contrib. Mineral. Petrol. 2020, 175. [CrossRef]

19. Vitale-Brovarone, A.; Groppo, C.; HetÉNyi, G.; Compagnoni, R.; Malavieille, J. Coexistence of lawsonite-bearing eclogite and blueschist: Phase equilibria modelling of Alpine Corsica metabasalts and petrological evolution of subducting slabs. J. Metamorph. Geol. 2011, 29, 583-600. [CrossRef]

20. Fabbri, O.; Magott, R.; Fournier, M.; Etienne, L. Pseudotachylyte in the Monte Maggiore ophiolitic unit (Alpine Corsica): a possible lateral extension of the Cima di Gratera intermediate-depth Wadati-Benioff paleo-seismic zone. Earth Sci. Bull. 2018, 189, 18. [CrossRef]

21. Vitale-Brovarone, A.; Beltrando, M.; Malavieille, J.; Giuntoli, F.; Tondella, E.; Groppo, C.; Beyssac, O.; Compagnoni, R. Inherited Ocean-Continent Transition zones in deeply subducted terranes: Insights from Alpine Corsica. Lithos 2011, 124, 273-290. [CrossRef]

22. Vitale-Brovarone, A.; Picatto, M.; Beyssac, O.; Lagabrielle, Y.; Castelli, D. The blueschist-eclogite transition in the Alpine chain: $\mathrm{P}-\mathrm{T}$ paths and the role of slow-spreading extensional structures in the evolution of HP-LT mountain belts. Tectonophysics 2014, 615-616, 96-121. [CrossRef]

23. Ravna, E.J.K.; Andersen, T.B.; Jolivet, L.; de Capitani, C. Cold subduction and the formation of lawsonite eclogite - Constraints from prograde evolution of eclogitized pillow lava from Corsica. J. Metamorph. Geol. 2010, 28, 381-395. [CrossRef]

24. Caron, J.-M.; Péquignot, G. The transition between blueschists and lawsonite-bearing eclogites based on observations from Corsican metabasalts. Lithos 1986, 19, 205-218. [CrossRef]

25. Brunet, C.; Monié, P.; Jolivet, L.; Cadet, J.-P. Migration of compression and extension in the Tyrrhenian Sea, insights from 40Ar/39Ar ages on micas along a transect from Corsica to Tuscany. Tectonophysics 2000, 321, 127-155. [CrossRef]

26. Vitale-Brovarone, A.; Beyssac, O.; Malavieille, J.; Molli, G.; Beltrando, M.; Compagnoni, R. Stacking and metamorphism of continuous segments of subducted lithosphere in a high-pressure wedge: The example of Alpine Corsica (France). Earth-Sci. Rev. 2013, 116, 35-56. [CrossRef]

27. Vitale-Brovarone, A.; Herwartz, D. Timing of HP metamorphism in the Schistes Lustrés of Alpine Corsica: New Lu-Hf garnet and lawsonite ages. Lithos 2013, 172, 175-191. [CrossRef]

28. Austrheim, H.; Andersen, T.B. Pseudotachylytes from Corsica: Fossil earthquakes from a subduction complex. Terra Nova 2004, 16, 193-197. [CrossRef]

29. Plunder, A.; Agard, P.; Chopin, C.; Okay, A.I. Geodynamics of the Tavşanlı zone, western Turkey: Insights into subduction/obduction processes. Tectonophysics 2013, 608, 884-903. [CrossRef]

30. Topuz, G.; Okay, A.; Altherr, R.; Meyer, H.P.; Nasdala, L. Partial high-pressure aragonitization of micritic limestones in an accretionary complex, Tavşanlı Zone, NW Turkey. J. Metamorph. Geol. 2006, 24, 603-613. [CrossRef]

31. Okay, A.I.; Harris, N.B.; Kelley, S.P. Exhumation of blueschists along a Tethyan suture in northwest Turkey. Tectonophysics 1998, 285, 275-299. [CrossRef]

32. Pourteau, A.; Scherer, E.E.; Schorn, S.; Bast, R.; Schmidt, A.; Ebert, L. Thermal evolution of an ancient subduction interface revealed by Lu-Hf garnet geochronology, Halilbağ1 Complex (Anatolia). Geosci. Front. 2019, 10, 127-148. [CrossRef]

33. Sherlock, S.; Kelley, S.; Inger, S.; Harris, N.; Okay, A. 40 Ar-39 Ar and Rb-Sr geochronology of high-pressure metamorphism and exhumation history of the Tavsanli Zone, NW Turkey. Contrib. Mineral. Petrol. 1999, 137, 46-58.

34. Davis, P.B.; Whitney, D.L. Petrogenesis and structural petrology of high-pressure metabasalt pods, Sivrihisar, Turkey. Contrib. Mineral. Petrol. 2008, 156, 217-241. [CrossRef]

35. Davis, P.B.; Whitney, D.L. Petrogenesis of lawsonite and epidote eclogite and blueschist, Sivrihisar Massif, Turkey. J. Metamorph. Geol. 2006, 24, 823-849. [CrossRef]

36. Malavieille, J.; Chemenda, A.; Larroque, C. Evolutionary model for Alpine Corsica: Mechanism for ophiolite emplacement and exhumation of high-pressure rocks. Terra Nova-Oxf. 1998, 10, 317-322. [CrossRef] 
37. Danišík, M.; Kuhlemann, J.; Dunkl, I.; Evans, N.J.; Székely, B.; Frisch, W. Survival of ancient landforms in a collisional setting as revealed by combined fission track and (U-Th)/He thermochronometry: A case study from Corsica (France). J. Geol. 2012, 120, 155-173. [CrossRef]

38. Panozzo, R. Two-dimensional strain from the orientation of lines in a plane. J. Struct. Geol. 1984, 6, 215-221. [CrossRef]

39. Park, M.; Jung, H. Analysis of electron backscattered diffraction (EBSD) mapping of geological materials: Precautions for reliably collecting and interpreting data on petro-fabric and seismic anisotropy. Geosci. J. 2020, 24, 679-687. [CrossRef]

40. Skemer, P.; Katayama, I.; Jiang, Z.; Karato, S.-i. The misorientation index: Development of a new method for calculating the strength of lattice-preferred orientation. Tectonophysics 2005, 411, 157-167. [CrossRef]

41. Sinogeikin, S.V.; Schilling, F.R.; Bass, J.D. Single crystal elasticity of lawsonite. Am. Mineral. 2000, 85, 1834-1837. [CrossRef]

42. Bezacier, L.; Reynard, B.; Bass, J.D.; Wang, J.; Mainprice, D. Elasticity of glaucophane, seismic velocities and anisotropy of the subducted oceanic crust. Tectonophysics 2010, 494, 201-210. [CrossRef]

43. Mainprice, D. A FORTRAN program to calculate seismic anisotropy from the lattice preferred orientation of minerals. Comput. Geosci. 1990, 16, 385-393. [CrossRef]

44. Walton, W. Feret's statistical diameter as a measure of particle size. Nature 1948, 162, 329-330. [CrossRef]

45. Fujimoto, Y.; Kono, Y.; Hirajima, T.; Kanagawa, K.; Ishikawa, M.; Arima, M. P-wave velocity and anisotropy of lawsonite and epidote blueschists: Constraints on water transportation along subducting oceanic crust. Phys. Earth Planet. Inter. 2010, 183, 219-228. [CrossRef]

46. Keppler, R.; Behrmann, J.H.; Stipp, M. Textures of eclogites and blueschists from Syros island, Greece: Inferences for elastic anisotropy of subducted oceanic crust. J. Geophys. Res. Solid Earth 2017, 122, 5306-5324. [CrossRef]

47. Abdullah, S.; Misra, S.; Sarvesha, R.; Ghosh, B. Resurfacing of deeply buried oceanic crust in Naga Hills Ophiolite, North-East India: Petrofabric, microstructure and seismic properties. J. Struct. Geol. 2020, 139. [CrossRef] 